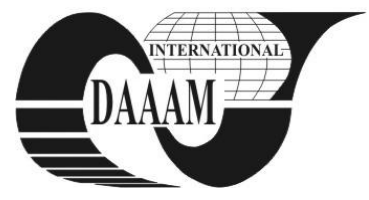

\title{
DEFERRED TAXES CONTRIBUTION TO THE INCREASE OF THE FINANCIAL INFORMATION'S REALISM
}

\author{
ISTUDOR, I[leana] I[ulia]; PREDESCU, L[orena]; NISTOR, N[icoleta] \& MOCANU, F[lorina]
}

\begin{abstract}
The conducted research has shown the way the result of the analysed company is influenced by using the international financial reporting standards. Carried out in a Romanian company activating in the civil engineering and infrastructure domain, the conducted research revealed the advantage of using deferred taxes in presenting a true image of the company's financial statements with impact on the company's result.
\end{abstract}

Key words: financial information, international financial reporting standards, deferred tax, accounting result, tax result

\section{INTRODUCTION}

In global acceptance the company's result represents the main indicator that describes its performance and the one of its management team. Its presentation in the financial statements constitutes one of the main informational resources given to the external environment. In order to understand this information, it must be submitted in a unique, coherent and concise form. This was achieved by developing the international standards (IFRS) which represent a globalization product. The communication in a unique language provides a greater level of trust and leads to the growth of access possibilities to capital market (Diaconu, 2006).

International accounting doctrine envisages two types of distortions between the accounting result and the tax result which manifest as permanent differences and temporary differences (Cernuşcă, 2007).

The deferred taxes accounting contributes to achieving the objective of true image by taking into account the temporary differences arising between the tax treatment and the accounting treatment of the same operation.

From this point of view it is estimated that deferred taxes can be considered as a technique of transcribing taxation in accounts in order to make them more realistic and to place them in a dynamic concept (Morgenstern, 2011).

In the process of economic globalization the adoption of new standards for reporting the company's financial performance brought a number of concepts and new approaches that have significantly influenced the result's determination (Istudor \& Mocanu, 2011)

\section{METHODOLOGY}

The undertaken research started from the assumption that the use of deferred taxes presents influences on the realism of accounts and implicitely on the company's result.

The complexity of the proposed research within this study has required, next to a theoretical research also an applied research, on a case study, so as to fully and consistently reflects the documentary information as well as its interpretation perspectives. The purpose of the research's approach constituted the improvement of the way to knowledge the influence of deferred taxes on financial statements, in the context of economic globalization and standardization of the financial accounting information.

\section{THE INFLUENCE OF USING DEFERRED TAXES ON THE COMPANY'S RESULT}

In the performed case study we realised a simulation of the influence of deferred taxes on the company's result, taking into account the impact of temporary differences on the result (Table no. 1).

\begin{tabular}{|c|c|c|c|}
\hline Year & $\begin{array}{c}2008 \\
\text { (lei) }\end{array}$ & $\begin{array}{c}\begin{array}{c}2009 \\
\text { (lei) }\end{array} \\
\end{array}$ & $\begin{array}{c}\begin{array}{c}2010 \\
\text { (lei) }\end{array} \\
\end{array}$ \\
\hline $\begin{array}{l}\text { Deductible elements } \\
\text { influence } \\
\text { (repair costs } \\
\text { reconsideration) }\end{array}$ & $-30,000$ & 0 & 0 \\
\hline $\begin{array}{l}\text { Non-deductible elements } \\
\text { influence (accounting } \\
\text { depreciation as against tax } \\
\text { depreciation) }\end{array}$ & 10,000 & 10,000 & 10,000 \\
\hline Influence Result & $-20,000$ & 10,000 & 10,000 \\
\hline Accounting Result & 307,297 & $1,937,195$ & 654,153 \\
\hline $\begin{array}{l}\text { Taxable Result } 1 \text { (prior to } \\
\text { permanent differences } \\
\text { influence) }\end{array}$ & 287,297 & $1,947,195$ & 664,153 \\
\hline $\begin{array}{l}\text { Accounting Result } \\
>\text { Taxable Result } \\
\end{array}$ & Yes & No & No \\
\hline $\begin{array}{l}\text { Taxable temporary } \\
\text { difference }\end{array}$ & 20,000 & $* * *$ & $* * *$ \\
\hline Tax rate & $16 \%$ & $16 \%$ & $16 \%$ \\
\hline Deferred tax liability & 3,200 & $* * *$ & $* * *$ \\
\hline $\begin{array}{l}\text { Accounting Result } \\
\text { < Taxable Result } \\
\end{array}$ & No & Yes & Yes \\
\hline $\begin{array}{l}\begin{array}{l}\text { Deductible temporary } \\
\text { difference }\end{array} \\
\end{array}$ & $* * *$ & 10,000 & 10,000 \\
\hline Tax rate & $16 \%$ & $16 \%$ & $16 \%$ \\
\hline Deferred tax claim & $* * *$ & 1,600 & 1,600 \\
\hline $\begin{array}{l}\text { Influence of other } \\
\text { elements: tax } \\
\text { nondeductible / tax } \\
\end{array}$ & $2,512,566$ & $2,581,236$ & $2,456,017$ \\
\hline \begin{tabular}{|l|} 
deductions (permanent \\
differences taken into \\
account when calculating \\
the tax due)
\end{tabular} & $-2,450,217$ & $-2,601,907$ & $-2,369,259$ \\
\hline Final Taxable result & 349,646 & $1,926,524$ & 750,911 \\
\hline Tax rate & $16 \%$ & $16 \%$ & $16 \%$ \\
\hline Current income tax & 55,943 & 308,244 & 208,996 \\
\hline Sponsorship expenses & 8,000 & 47,500 & 350 \\
\hline Paid income tax & 47,943 & 260,744 & 208,646 \\
\hline
\end{tabular}

Tab. 1. Influences determined by the fiscal approach 
At the time of the research the company applied the national accounting regulations (OMFP no. 3.055/2009). Romania's legislation provides that the current tax method (chargeable tax) should be used in the accounting system. In this case within the tax expenses of the period the current tax (chargeable tax) is recognized. Following the conducted research we consider that the need of using deferred taxes (IAS 12 Income taxes) starts from the deficiency of taking into account only the tax due for the correct interpretation of the tax effects' allocation on the operations to which they relate.

In connection with the income tax accounting treatment (in the sense of IAS 12 Income Taxes) we consider that the occured problems are related to the way of recording in accounting the current and future tax consequences of the forthcoming recovery of the assets'/liabilities' book value which are recognized in the company's statement of financial position as well as the transactions and events of the current period which are recognized within the company's financial statements (IASB, 2009).

For this, in terms of accounting, we considered necessary to reconsider certain expenses. We assumed that the value of 30,000 lei from the expenses made in 2008 on equipments repairs was related to the improvement of equipment's technical performance. This reconsideration led to the capitalization of the amount of 30,000 lei to the remaining depreciated value of the equipment. The capitalized amount will be amortized during the equipment's remaining period of use (3 years). The used depreciation method is the straight-line depreciation.

From the analysis of the obtained effects resulted that while accounting capitalizes in the value of the equipment the expense related to its modernization, the tax approach includes it in the profit and loss account as an expense related to repair. In terms of accounting the capitalized works will be found in the company's result in the analysed period. This will materialize into an income tax to be paid in the future. In this respect in 2008 resulted a taxable temporary difference that will lead to the recording of a debt concerning the deferred tax of 3,200 lei. This debt will be supported by the company during 2009, 2010.

Deferred tax's influence on the profit and loss account during the period $2008-2010$ is presented in the table no. 2

\begin{tabular}{|c|c|c|}
\hline \multirow[b]{2}{*}{ Explanation } & \multicolumn{2}{|c|}{ Method of } \\
\hline & $\begin{array}{c}\text { Curent tax } \\
\text { (lei) }\end{array}$ & \begin{tabular}{|c|}
$\begin{array}{c}\text { Deferred tax } \\
\text { (lei) }\end{array}$ \\
\end{tabular} \\
\hline \multicolumn{3}{|l|}{ Year 2008} \\
\hline Accounting result & 307,297 & 307,297 \\
\hline Current tax expenses & $-47,943$ & 47,943 \\
\hline Deferred tax expenses & 0 & 3,200 \\
\hline Net result & 259,354 & 256,154 \\
\hline \multicolumn{3}{|l|}{ Year 2009} \\
\hline Accounting result & $1,937,195$ & $1,937,195$ \\
\hline Current tax expenses & $-260,744$ & $-260,744$ \\
\hline Deferred tax expenses & 0 & 1,600 \\
\hline Net result & $1,676,451$ & $1,678,051$ \\
\hline \multicolumn{3}{|l|}{ Year 2010} \\
\hline Accounting result & 654,153 & 654,153 \\
\hline Current tax expenses & $-208,646$ & $-208,646$ \\
\hline Deferred tax expenses & 0 & 1,600 \\
\hline Net result & $-445,507$ & $-447,107$ \\
\hline
\end{tabular}

Tab. 2 - Deferred tax's influence on the company's income during 2008 - 2010

A correct application of the principle of connecting expenses to revenues leads to the necessity of a registration that transfers the tax's accounting effect. In our opinion the recognition of a debt concerning the deferred tax in the fiscal year 2008 can be seen as well as a cautious approach of the company's management which prefers an allocation of tax costs related to assets during their useful life. This registration will present as effect the placement in an additional period of the accounting effect of the tax associated to the considered operation. In this respect, we consider that the application of IAS 12 Income Taxes is a process a difficult to implement. This is due to the necessity of recording in accounting the current and future tax consequences of the forthcoming recovery of the assets' / liabilities' book value recognized in the statement of financial position of the company. In Romania, the application of IAS 12 would result in changes for wich taxation is not ready yet.

As future research perspectives we propose the following actions: first, reveal the impact of applying IFRS in their entirety on the result of the company was analyzed and second, identification of the IFRS implementation impact in the individual accounts of the Romanian enterprises on the budgetary receipts.

\section{CONCLUSION}

Following the undertaken research we can conclude that the international financial reporting standards (particularly IAS 12 Income Taxes) deal with the company's financial result from two points of view, accounting and taxation. The differences arising between the accounting result and the tax result and which do not present fiscal repercussions on the taxes of future periods represent permanent differencies. These do not give rise to deferred taxes.

Temporary differences between the accounting result and tax result come from the time gap occurred between the moment an element is recorded in acounting and its inclusion in the tax result. Taking into consideration the temporary differences requires the recognition of deferred taxes. By using deferred taxes, the financial statements provided by the companies will present the financial information very close to the real situation (true image). Thus we consider that the company's result will reflect the expense with the current income tax as well as the deferred tax expense, which will result in the provision of financial statements as close as possible to reality.

\section{REFERENCES}

Cernuşcă, L. (2007). Fiscal interferences in accounting, Tribune Publishing House, Bucharest

Diaconu, G. (2006). International Accounting. Comparisons and harmonizations, II $^{\text {nd }}$ edition, Bibliotheca Publishing House, Târgovişte

Istudor, I. \& Mocanu, F. (2011). Globalization determinant factor of the vulnerability enterprise's result, Proceedings of The Global Conference on Business and Finance, May 24-27, 2011, San Jose Costa Rica, ISSN 1941-9589, Jalbert, T. (Ed.), pp. 440-448, The Institute for Business and Finance Research, HILO, HI 96720, U.S.A.

Morgenstern, P. (2011). Les impôts différés, Groupe Revue Fiduciaire, Paris.

*** (2009) IASB - International Financial Reporting Standards: IFRS: official rules issued on January the $1^{\text {st }}, 2009$, for International Accounting Standards Committee Foundation, $4^{\text {th }}$ edition revised (CECCAR translation), CECCAR Publishing House, Bucharest, 2009.

*** (2009) OMFP no. 3.055/2009, Order of the Minister of Public Finances, for the approval of Accounting Regulations in accordance with European Directives, published in the Romanian Official Gazette, Part I, no. 766 bis from 10/11/2009 